\title{
Consequences of Poor Landfill Management on the People of Gbalahi in the Sagnarigu Municipality of Northern Ghana
}

\author{
Tijani Inusah Iddrisu1 ${ }^{1}$, Kwame Donkor Debrah ${ }^{2}$ \\ ${ }^{1}$ Department of Sustainable Development Studies, University for Development Studies, Tamale, Ghana \\ ${ }^{2}$ Works and Physical Development Directorate, University for Development Studies, Nyankpala, Ghana \\ Email: ahmedyelisumah@gmail.com,donkorkwame38@gmail.com
}

How to cite this paper: Iddrisu, T. I., \& Debrah, K. D. (2021). Consequences of Poor Landfill Management on the People of Gbalahi in the Sagnarigu Municipality of Northern Ghana. Journal of Geoscience and Environment Protection, 9, 211-224.

https://doi.org/10.4236/gep.2021.98014

Received: July 7, 2021

Accepted: August 27, 2021

Published: August 30, 2021

Copyright $\odot 2021$ by author(s) and Scientific Research Publishing Inc. This work is licensed under the Creative Commons Attribution International License (CC BY 4.0).

http://creativecommons.org/licenses/by/4.0/

\begin{abstract}
The management of municipal solid waste (MSW) has become a matter of great concern. As a result of this, there have been strenuous efforts at all levels geared towards addressing this menace. Although there are several methods of disposing of waste, landfills remain one of the outstanding management systems in dealing with the growing quantum of generated municipal solid waste. This study assessed the consequence of poor landfill management from the perspective of the Gbalahi landfill in the Sagnarigu Municipality in Northern Ghana. The study employed interviews to gather information from 103 households. The acquired data was supported by some secondary data from the site management and the municipal environmental unit. The study revealed that poor management of the facility has led to the breakdown of some major components of the facility. It was also noted that the site poses a threat to the health of the nearby communities owing to the uncontrolled dust, smoke, and activities of vermin as well as scavengers. The study concludes the Ghalahi landfill in its current state remains a threat to the health of the inhabitants of the area. Poor management of equipment and failure to adhere to best practices has exacerbated conditions of their operation putting the health of the people in danger. Regular monitoring of the site by the EPA and the local government authorities can help reduce the risk of exposure on the nearby communities.
\end{abstract}

\section{Keywords}

Waste, Management, Landfill, Gbalahi, Sagnarigu

\section{Introduction}

In most developing countries, poor management of municipal solid waste (MSW) 
has impacted negatively on the environment (Magda et al., 2015). As a result of this, there have been strenuous efforts at all levels geared towards addressing this menace (Hilburn, 2015). The focuses of these actions have been the promotion of strategies concerning the holistic management of waste. Although there are several methods of disposing of waste, landfills remain one of the outstanding management systems in dealing with the growing quantum of generated municipal solid waste, thus, landfills have been used to manage MSW for quite some time. However, the advent of sanitary landfills with more proven methods of reclamation has been ideal (McAllister, 2015).

As the human population grows, the amount of solid waste generated keeps soaring as well. In the last ten years, the quantum of generated waste has doubled globally and it is predicted to be approximately 2.5 billion tons annually by the year 2025 (Nathanson, 2015). This excessive increase is directly related to the increased rate of urbanization and the shifting pattern of consumption (Périou, 2012). This, therefore, brings to the forth how this waste will be managed. Studies have shown that landfilling over the years has proven to be the most effective management tool of MSW (Al-Khatib et al., 2015; Hilburn, 2015).

Landfills usage is well known in both the developed and developing world. In Europe for instance, policies of reuse of waste, recycling, and reduction of waste have been heavily promoted despite a large chunk of municipal solid waste still goes to landfills (Aljaradin \& Persson, 2012). Among communities in the developing world, people resort to improper landfilling systems such as open dumping which often remain a threat to human health and the environment (Al-Khatib et al., 2015). The use of engineered landfills is uncommon in most developing countries despite the rapid rate of urbanization and its concomitant increase in municipal waste (Owusu et al., 2012; George et al., 2014). In certain instances, sanitary landfills that are used in most developing countries are operated under poorly managed operational systems. Very often than not, exposure of municipal solid waste to rain results in some decomposition leading to the formation of leachate (Valencia et al., 2009). This dissolved and suspended materials if not properly controlled, may pass through the underlying soil and contaminate sources of drinking water, as well as surface water" (ISWA, 2015).

Generally, leachate contains heavy metals such as iron, copper, manganese, nickel, lead, and other elements such as calcium, magnesium chromium, nitrogen, potassium, and ammonia. Often, compounds such as phenols, polyaromatic hydrocarbons, acetone, benzene, toluene, and chloroform are formed as well (Valencia et al., 2009; Irma et al., 2016). Leachate resulting from the landfill is therefore regarded as a dangerous waste substance often difficult to manage because of the prevalence of these heavy metals and compounds. The adverse effects of these metals are numerous and depend largely on the type and age of solid waste of a landfill (Schoeman et al., 2003). Available information paints a gloomy picture and puts sufferers and those exposed to leachate at high risks due to the heavy metal accumulation. A lot of the adverse impacts result directly 
from an emission in a form of Persistent Organic Compounds (POC) and Volatile Organic Compounds (VOC). Pollution from landfills is great and it's estimated to produce about 40 million tons of methane annually, a gas with a greater propensity of depleting the ozone (ISWA, 2015).

As a result of the enormous risks associated with landfills, its treatment has not also been easy. In the recent past, the use of anaerobic digestion or the aerobic activated sludge method was mainly used but these methods appeared inappropriate for certain complex treatments. However, there have been more rigorous scientific approaches recently focusing more on biological, chemical, and physical methods of treatment. The Sequencing Batch Reactor (SBR) has been used lately by several countries. For most recent biological treatments, the aerobic treatment consisting of ion-exchange is first of all applied (Schoeman et al., 2003). The use of chemical oxidants such as Fenton's reagent and UV light is also very commonly used (Kasam \& Agus, 2016; Schoeman et al., 2003). In Ghana, MSW management is faced with a myriad of challenges ranging from finance, infrastructure, and human resources (Owusu et al., 2012; Owusu-Sekyere et al., 2013). It is common to find waste been damped on old quarry sites and unregulated landfills. These landfills remain the endpoint of about $55 \%$ of the total waste generated in the Accra Metropolis alone (Kasam \& Agus, 2016). The Oblogo Landfill is a classic example of these landfills. The resultant leachate from this remains a threat to the surrounding environs.

In northern Ghana, the Gbalahi Landfill remains the only engineered sanitary landfill serving the Tamale Metropolis and the Sagnarigu Municipality in particular and other adjoining districts at large (Puopiel \& Owusu-Ansah, 2014). The landfill which was opened in 2004 is partitioned into two units with one unit already full and the other unit being in operation. There are three ponds with the first two covering a total land area of $1216 \mathrm{~m}^{2}$ each and the third pond is 2432 $\mathrm{m}^{2}$. These three ponds are connected to an aerobic pond of $4464 \mathrm{~m}^{2}$. These ponds operate in alternation and thus the secondary pond is opened when the liquid waste in the primary pond rises (Issahaku, 2014).

The landfill receives an average of 810 tons of collected waste daily with an annual projected increase of about 160 tons (Puopiel \& Owusu-Ansah, 2014; Osahon, 2019). Being the only landfill and serving a huge growing population, concerns have grown over the last few years about the management of the site. The complexity in the construction of engineered landfills lies in the attainment and continuous maintenance and adherence to environmental standards (Thompson, 2012). Although engineered land sites have a greater capacity to enhance environmental quality, poorly managed ones also pose a great danger to the surroundings and humans as well (Manisalidis, 2020). Even though the Local Government Act of 1994 (Act 462) and the Environmental Sanitation Policy (ESP) of 1999 (revised 2008) has explicit general guidelines for construction and maintenance of landfill in Ghana, weak infrastructure from municipal authorities have not helped the situation (Owusu-Sekyere et al., 2013). In Ghana, even 
though regulatory powers of the environment lie in the bosom of the Environmental Protection Agency (EPA), the management of waste is the responsibility of the Local government ministry.

The dangers associated with poorly managed landfills are enormous. Leachate has a greater tendency of continuous activity several years after the closure of a landfill site (Buso et al., 2015; Ugwoha \& Emete, 2015). Inappropriately managed landfills could affect food, water, and air thereby affecting human health (George et al., 2014). This study assessed the environmental consequence of poor landfill management in reference to the Gbalahi Landfill in the Tamale Metropolis of Ghana.

\section{Literature Review}

\subsection{Types of Landfill}

A landfill site is a facility for the disposal of solid waste by burial. It is the oldest form of waste disposal. A landfill site is also referred to as a tip or dump (Zhu, et al., 2008). Landfilling is predominantly used in low-income countries due to its economic advantages (Elliott et al., 2009). The disadvantages of landfills are that landfills and their surrounding areas are often heavily polluted. This leads to water, air, and soil pollution through the spread of dangerous chemicals into the water table or into waterways (Buso et al., 2015).

As noted by most studies (Owusu-Sekyere et al., 2013; Ugwoha \& Emete, 2015) landfill sites are classified as engineered and conventional landfill sites. Engineered landfill sites are also referred to as sanitary landfills. Sanitary landfills are specially built landfills, which reduce the harmful effects of dumping. A sanitary landfill is a disposal site designed, constructed, operated, and maintained to minimize the potential environmental impact of deposited waste. Engineered landfills have appropriate liners for groundwater protection, sumps for leachate collection, leachate treatment systems, groundwater monitoring wells, landfill gas collection systems, and appropriate final cover design (Elliott et al., 2009).

\subsection{Landfill Site Selection and Operation}

Selection of land for landfill site construction is a major challenge due to the required level of public acceptance. Several studies have highlighted cases of local societies' revolt against landfill placement in their community (Annorbah, 2014; Magda et al., 2015). According to the (DWAF, 1998), citing a landfill far away from residential areas, industrial units, archaeological sites, airports, military establishments, forest or reforested areas, protected areas, or areas of ecological importance is ideal. In the same vein, landfills are to be sited away from flood plains and wetlands to prevent contamination of the underground water system. Aside from the environmental criteria as identified above, (Syeda et al., 2014) recognized that issues relating to social acceptance, residential pressure, property status, farming and animal-raising activity, use of groundwater by residents, and current aesthetic status are equally important. 
Another criterion emphasized by (ISWA, 2015) is hydro-geological criteria and it relates directly to aquifer characteristics that are the depth and topsoil and subsoil conditions. The sensitivity of groundwater recharge areas and deepwater table to prevent leakage of leachate into groundwater. The soil of site should have low permeability and a thick impermeable subsoil layer. (Ugwoha \& Emete, 2015) also mention functional criteria which concentrated on the availability of cover material, transportation networks and accessibility, and climatic conditions including rainfall height, intensity, and frequency (Magda et al., 2015).

\subsection{Composition and Characteristics of Leachates}

In the waste management streams, disposal of municipal solid waste has been a major challenge (Ayari et al., 2010). Dumpsite and landfills remain the popular mechanism of MSW disposal throughout the world (MDHSS, 2018). At these sites, the deposited waste produces and emits hazardous chemicals including poisonous liquid which gradually seep underground. This liquid is often described as leachates (Aziz et al., 2015; Samuel, 2014). Leachate consists of soluble compounds consisting of water, organic and inorganic as well as bacterial laden compounds. The organic compounds include alcohols, acids, aldehydes, short-chain sugars (Annorbah, 2014). (Kasam et al., 2016) noticed the complexity in the composition coupled with the activities of vermin has a direct effect on the liquid produced. The composition of leachates, therefore, depends on the nature of the site, the stage of the site in years, the level of exposure to rainfall as well as the quantum of waste deposited (Malyuba et al., 2013).

The resultant chemical reactions in the deposited waste produce leachate mainly from the multiple chemical and biological reactions of solid waste within the landfill and can be a major contamination problem if not controlled properly (Ebikapade \& Baird, 2016). The resultant chemical reactions and subsequent production of leachate are a source of health and environmental problems which implies the necessity for leachate treatment before its ultimate disposal (Foday \& Quangyen, 2013).

The general determination of leachate is based on the physical and chemical properties and the chemical oxygen demand (COD) with the main precursors being the presents of heavy metals (DWAF, 1998). According to (Liu et al., 2015), most leachate is orange dark brown with some kind of malodorous smell. This is often influenced heavily by the presence of organic acid resulting from the decomposition of the deposited waste. As the landfill grows older, the color of the leachate changes but this may also be as a result of the amount of exposure to various forms of precipitation (Liu et al., 2015). The Potential Hydrogen (pH) present in leachate ranges from 4.5 to 9 (Annorbah, 2014). At the early stage, however, the $\mathrm{pH}$ is usually lower than 6.5 resulting in some level of acid content mainly due to the concentration of volatile acids (Nang et al., 2017). The pH could rise up to 7.5 eventually making the leachate alkaline (Mudo et al., 2016). The BOD and COD measure the demand for oxygen in the leachates. 


\subsection{Management of Landfill Site and Health of Nearby Communities}

Generally, landfills are a major source of hazards due to the continuous decomposition and fermentation of municipal solid waste. This is very common with landfills that are poorly covered increasing the exposure of the landfill to insects, pests, and vermin (Yadav et al., 2018). A study by (Owusu-Sekyere et al., 2013) found that vermin feed on poorly managed landfills and this leads to their multiplication. This, therefore, increases the tendency of disease spread through a series of contamination of food and water outside the landfill as the activities of vermin are not limited to the site alone. The flatworm, the segmented worm as well as insects and rodents for instance are major carriers of diseases resulting from the landfill (Samuel, 2014). For some of the insects like the fly, the condition such as the gaseous heat from the landfill is a major precursor to their growth and development. The spread of diseases from the landfill is not common to insects only but birds also which together with the insects and vermin act as disease vectors (Owusu-Sekyere et al., 2013).

Also (Aminul et al., 2013) studied the effects of wind-blown dust and heavy concentration of smoke which deteriorates the ambience of communities near landfills. Continuous exposure to a contaminated atmosphere is a major source of respiratory difficulties. Aside from the contamination of the atmosphere, (Aziz et al., 2015) also identified the contamination of groundwater through leachate generation to be a major health problem. This is common where the landfill is not lined coupled with prolonging poor management. The chemical composition of the underground water, therefore, becomes contaminated Subsequent seepage of leachate increases the formation of trace metals in underground water. There is also the production of landfill gases such as methane, carbon dioxide, sulphur oxide, volatile compounds, and nitrogenous compounds (Fazzo, 2011). The effects of these gases on plants and animals are enormous. As a result of the free mobility of gases, these effects usually go beyond the site of contamination.

A publication by (Elliott et al., 2001) with the objective of looking at the adverse birth outcomes in people living close to landfill noticed that, the risk and effects of pollutants on unborn children and other neonatal effects were found to be high. Effects such as body irritation, eye itching, hypersensitivity, and skin rushes were common. Other side effects that were noticed were linked to the odor and stench coming from the site. Related diseases included, include irritation of skin, nose \& eyes, allergies, psychological disorders, headache, fatigue, nausea and gastrointestinal problems occurs.

\section{Materials and Methods}

The study adopted the survey research design with the concurrent mixed methods strategy where quantitative data was mainly used (Creswell, 2009). Data was taken from both primary and secondary sources from respondents using questionnaires and observation. A separate questionnaire was used on the two 
categories of respondents; that is the people living close to the landfill and the management of the landfill. With the use of the questionnaire and observation, primary data was collected and complemented by the available secondary data.

A preliminary visit was made to the site through a transect walk in both the communities and the landfill in order to observe the activities from the site. This was done to acquaint the researcher with firsthand information on the mode of operation of the facility and to establish the situational perspective from the community members. During the walk, the researcher engaged the residents in unstructured discussion in order to establish at first hand, the nature of the relationship of the landfill with the community.

Simple Random Sampling technique was used to select four communities around the landfill enclave (Puopiel \& Owusu-Ansah, 2014). In all, 103 households were randomly chosen. Purposive sampling was used to select respondents from the management of the landfill site. Data was analyzed using the SPSSv.20 and output was expressed in figures and tables. Secondary data was carefully reviewed and used to support the primary data collected.

\section{Results and Discussion}

\subsection{Proximity of Residents to the Gbalahi Landfill Site}

Several studies have sought to determine the risk posed to communities close to a landfill. The risk pose to the population around landfills is not limited to dust, smoke, and noise but also the exposure to gaseous chemicals. The study first all examined the proximity of residents to the Gbalahi landfill site. This was done in order to identify the extent of risk of exposure in terms of proximity of respondents to the site. The result from the study revealed that $10.7 \%$ of the respondents live less than 50 meters from the landfill site. Respondents who lived from 50 meters to 100 meters represented $33.0 \%$ of the respondents. This means that about one-third of the respondents live within 100 meters radius away from the Gbalahi landfill site. This could have some serious implications on the level of exposure and consequently the health of residents since close proximity could lead to greater exposure to negative externalities from the site. These externalities could be dust, odor, and smoke among others. Still, in Table 1, data from the study showed a little percentage $(1 \%+4.9 \%)$ of respondents living one kilometer away from the site. This suggests also that, in terms of proximity to the site and exposure, as little as $5.9 \%$ of residents are less likely to be exposed to any form of direct contamination from the site. It was also observed that, these residents who lived had encroached the buffer zone.

On the proximity of the site to residents, site managers indicated that the risk to exposure is dependent on the closeness to the site. This assertion was not different from that of that, people living $2 \mathrm{~km}$ to the site stand a high risk of contamination than those farther away. Associated effects due to exposure include leukemia, in children and birth defects as well as nervous breakdown (DWAF, 1998). The fact that the majority of the respondents live very close to the site indicates the risk they are exposed to. In Table 2, the required buffer for the 
Table 1. Distance of residents from the Gbalahi landfill site.

\begin{tabular}{ccc}
\hline Distance from landfill & Frequency & Percentage (\%) \\
\hline Less than $50 \mathrm{~m}$ & 11 & 10.7 \\
$50-100 \mathrm{~m}$ & 34 & 33.0 \\
$101-500 \mathrm{~m}$ & 30 & 29.1 \\
$501-1 \mathrm{~km}$ & 22 & 21.4 \\
$1 \mathrm{~km}-2 \mathrm{~km}$ & 1 & 1.0 \\
Above 2 km & 5 & 4.9 \\
Total & 103 & 100.0 \\
\hline
\end{tabular}

Source: 2021 Field Survey, Gbalahi Sagnarigu District.

Table 2. Required buffer for landfill in Ghana.

\begin{tabular}{ccc}
\hline \multirow{2}{*}{ Landfill Category } & \multicolumn{2}{c}{ Buffer Zone } \\
\cline { 2 - 3 } & Maximum distance in meters & Minimum distance in meters \\
\hline Metropolitan/Municipal & 600 & 300 \\
Large/Small Urban & 400 & 200 \\
Large Rural/Small Rural & 300 & 200 \\
\hline
\end{tabular}

Source: Ghana Landfill Guidelines (EPA, 2002).

landfill is indicated. contrary to the Gbalahi landfill site, it was observed that such buffer as indicated in the Ghana Landfill Guide is not been adhere to. The failure to adhere to these standards will thus expose a lot of people to the risk associated with the landfill. Studies (Annorbah, 2014; Nyame et al., 2012) noted that poor adherence to best practices and standards is one of the major causes of poor landfill management in developing countries.

During an interview with the site management, it was revealed that one of the major challenges over the years is the encroachment of the buffer zone. According to the officials, the encroachment began with construction of farmlands within the area, and gradually, these were turned into residential homes. Eventually, some residents started building permanent structures on the buffer. This resulted in the breakdown of the fence wire thereby exposing the facility to unrestricted entry. This suggests a poor or weak security system of the Gbalahi landfill site. The siting of farmlands in the area also poses a great threat to the health of the people. Surface run-off during the rainy season will more likely expose the farms to contamination with exposure to heavy metal contamination from the field. (Buso et al., 2015) underscored the need for protection of farmlands from run-off due to the potential dangers associated with landfills.

Another common danger of run-off from landfills is surface water pollution. Usually, communities who rely on surface water systems such as dams, streams, dug-outs, and natural wells are at a high risk of exposure to heavy metal contamination (ISWA, 2015). All the four communities sampled for the study used dams as their main domestic water source. As such, the risk of contamination is 
very high especially for the people close to the site. This situation was equally aggravated by the activities of scavengers who burnt electronic waste without any hindrance or regulation. In most instances, electronic wastes were bunted in open-air thereby exposing residents to smoke, and this hindered visibility.

\subsection{Common Sickness among Respondents}

The proximity of the residence in Gbalahi to the landfill site brought forth some major concerns. As a result of this, the study explored the common sicknesses in the area. This was done in order to determine the disease burden and to also establish which of these diseases are associated with the externalities of poor landfill management. The response was cross tabulated with the educational background of respondents as seen in Table 3. An analysis of the disease burden revealed cardiovascular related diseases, eye related infections, nostril congestions and hearing difficulties to be among the related health challenges.

It was revealed that significant difference existed between respondents without access to formal education and those with formal education in relation to the perceived sickness. As many as $56.2 \%$ of the respondents without formal education had experienced at least cardiovascular or chest-related sickness at least once in a lifetime as well as eye-related infections, nasal congestion, and hearing impairment than a combined total of those with primary to tertiary education. The high incidence of sickness among this category of respondents gives an indication that the educational background of respondents has an effect on how respondents relate to the negative externalities from the Gbalahi landfill.

As illustrated in Table 3, as many as $19.4 \%$ of respondents without access to formal education experienced hearing challenges with $9.6 \%$ of those with access to formal education experiencing the same. The disparity between those with access to formal education and those without access means that, educational background of respondents plays a key role in how respondents interact with the landfill site. Among those with access to education also revealed $9.7 \%$ of respondents in second cycle education are relatively low compared with respondents in the basic and tertiary levels of education respectively.

Table 3. Educational status and common sickness among respondents.

\begin{tabular}{|c|c|c|c|c|c|c|}
\hline \multicolumn{7}{|c|}{ Educational Status of Respondents ${ }^{*}$ What are these Sicknesses Cross tabulation } \\
\hline & & \multicolumn{4}{|c|}{ What are these Sicknesses } & \multirow[b]{2}{*}{ Total } \\
\hline & & $\begin{array}{c}\text { Cardio } \\
\text { Vascular/chest } \\
\text { pains }\end{array}$ & $\begin{array}{l}\text { Problems } \\
\text { with } \\
\text { eye sight }\end{array}$ & $\begin{array}{c}\text { Nostril } \\
\text { congestion }\end{array}$ & $\begin{array}{c}\text { Hearing } \\
\text { Impairment }\end{array}$ & \\
\hline \multirow{4}{*}{$\begin{array}{c}\text { Educational } \\
\text { Status of } \\
\text { Respondents }\end{array}$} & none & $16(15.5 \%)$ & $8(7.8 \%)$ & $14(13.5 \%)$ & $20(19.4 \%)$ & $58(56.2 \%)$ \\
\hline & Basic Education & $6(5.8 \%)$ & $2(1.9 \%)$ & $5(4.8 \%)$ & $5(4.8 \%)$ & $18(17.5 \%)$ \\
\hline & Second Cycle & $1(0.97)$ & 0 & $5(4.8 \%)$ & $4(3.8 \%)$ & $10(9.7 \%)$ \\
\hline & Tertiary & 0 & 0 & $11(10.7 \%)$ & $6(5.8 \%)$ & $17(16.5 \%)$ \\
\hline \multicolumn{2}{|c|}{ Total } & $23(22.3 \%)$ & $10(9.7 \%)$ & $35(34.1)$ & $35(34.1 \%)$ & $103(100 \%)$ \\
\hline
\end{tabular}

Source: 2021 Field Survey, Gbalahi Sagnarigu District. 
In order to better understand the prevalence of diseases in the community and to establish their relationship with the activities of the landfills or otherwise, the study, therefore, made use of the Outpatient Department Records at the Taha community clinic. This was to examine the top ten cases for at least three successive years. In Table 4, the ten top most sicknesses are shown. Of these ten, Upper Respiratory Tract Infections (URTI) which is commonly associated with particulate matter (smoke and dust) was found to be prevalent in these years. This corroborates respondents' perception of associating cardiovascular and nostril congestions to the activities in the landfill site. Again, the complaint of eye-related infections was mentioned and this also falls under the top ten cases. Although typhoid was not mentioned by respondents, it is also common among respondents within these three years. This suggests some infestation of water and food sources by vermin such as houseflies as this is often related to typhoid. The trend of the top ten common illnesses provides great insights into the exposure of respondents to the adverse impacts of the landfill. It is seen that illnesses related to exposure to particulate matter such as smoke and dust particles dominated. For all four years, Upper Respiratory Tract Infections, in particular, are among the first three common illnesses for the last three years. This gives credence to the effects of exposure to pollution from the landfill. The absence of other illnesses such as cancers and liver-related that are linked to heavy metal exposure are particularly absent from the ten common diseases for the periods under review. As expounded by (Ugwoha \& Emete, 2015), the effects of heavy metal exposure are usually commutative and may take a long time to show. Therefore the absence of it from the ten common illnesses does not necessarily indicate its absence but may be due to the way it takes time to manifest. Additionally, community clinic under the Ghana Health Service is not usually equipped to diagnose high level ailments such as cancer. This also explains why records of such category are not found.

Table 4. Top ten sickness in the Gbalahi landfill Site.

\begin{tabular}{ccccc}
\hline \multirow{2}{*}{ S/N-Rank } & \multicolumn{4}{c}{ Top Ten Sickness } \\
\cline { 2 - 5 } & 2016 & 2017 & 2018 & 2019 \\
\hline 1 & Malaria & Malaria & Malaria & Malaria \\
3 & Rheumatism & Rheumatism & U. R. T.I & U. R. T.I \\
4 & Skin diseases & U. R. T. I & Skin diseases & Eye infection \\
5 & U.R.T.I & Worn infestations & Typhoid & Typhoid \\
6 & Diarrhea & Diarrhea & Diarrhea & Diarrhea \\
7 & Typhoid & Typhoid & Rheumatism & Rheumatism \\
8 & Worn infestations & Anemia & Eye infection & Skin diseases \\
9 & Anemia & Skin Infection & Anemia & Anemia \\
10 & Pneumonia & Pneumonia & Pneumonia & Pneumonia \\
& Eye infection & Eye infection & Worn infestations & Worn infestations \\
\hline
\end{tabular}

Source: Taha Community Clinic. 
It was also observed that residents in the communities nearby were particularly exposed to dusty from both waste trucks and from the poor state of the roads. Some trucks did not have net cover thereby exposing waste to the wind. Some tracks with nets were more likely in bad shape of not appropriate since the flying of dust continued. The impact of the dust produced by the moving truck has some children keenly observing the movement of the truck. It was also observed that curious on-looking children in these communities were exposed to the risk of inhaling dust and other particulate matter. The cumulative effect of this could lead to respiratory problems and chronic lung problems.

\section{Conclusion}

From the above, it is seen that the consequence of poor landfill management of the Gbalahi landfill possess a danger to both environment and humans. From the above discussions, various categories of respondents are affected by the activities of the Gbalahi Landfill Site. Proximity from the site to the community is one major area of concern as residents keep battling with odor, dust, and smoke from the site. This results in the perceived increased incidents of respiratory, eye infections, and nostril congestions among other diseases. The cumulative impact of these may have dire consequences on people in the area in the medium to long run. Management of the site and the municipal authorities need to take the management of the site very seriously so as to keep the communities around the site free of any challenges. It is prudent that, the site operations are conducted with the best of care and under best practices in order to reduce the dust emanating from the road.

\section{Conflicts of Interest}

The authors declare no conflicts of interest regarding the publication of this paper.

\section{References}

Aljaradin, M., \& Persson, K. M. (2012). Environmental Impact of Municipal Solid Waste Landfills in Semi-Arid Climates-Case Study_Jordan. The Open Waste Management Journal, 5, 28-39. https://doi.org/10.2174/1876400201205010028

Al-Khatib, I., Kontogianni, S., Abu-Nabaa, H., Alshami, N., \& Al-Sari', M. I. (2015). Public Perception of Hazardousness Caused by Current Trends of Municipal Solid Waste Management. Waste Management, 36, 323-330. https://doi.org/10.1016/j.wasman.2014.10.026

Aminul, H., Hoque, M., Modal, U., \& Tauhid, M. S. A. (2013). Characterization of Leachate and Solid Waste of Dhaka City Corporation Landfill Site for Solid Waste Stabilization. American Journal of Civil Engineering and Architecture, 1. https://doi.org/10.12691/ajcea-1-2-3

Annorbah, R. (2014). Environmental Impacts of Active and Decommissioned Landfill Sites in the Accra Metropolis: A Case Study of the Painting and Mallam Landfill Sites. Thesis, University of Ghana.

Ayari, F., Hamdi, 1., Jedidi, N., Gharbi, N., \& Kossai, R. (2010). Heavy Metal Distribution 
in Soil and Plant in Municipal Solid Waste Compost Amended Plots. International Journal of Environmental Science and Technology, 7, 465-472. https://doi.org/10.1007/BF03326156

Aziz, S., Aziz, M., Bashir, M., \& Mojiri, A. (2015). Assessment of Various Tropical Municipal Landfill Leachate Characteristics and Treatment Opportunities. Global NEST Journal, 17, 439-450. https://doi.org/10.30955/gnj.001521

Buso, S., Nakin, M., Abraham, A., \& Musampa, M. (2015). Environmental and Community Impacts Soft Waste Disposal in OR Tambo District Municipality (South Africa). WIT Transactions on Ecology and the Environment, 193, 509-520. https://doi.org/10.2495/SDP150441

Creswell, J. (2009). Research Design. Sage Publications Inc.

DWAF (1998). Waste Management Series: Minimum Requirements for Waste Disposal by Landfill. DWAF.

Ebikapade, A., \& Baird, J. (2016). The Concept of Waste and Waste Management. Journal of Management and Sustainability, 6. https://doi.org/10.5539/jms.v6n4p88

Elliott, P., Briggs, D., Morris, S., de Hoogh, C., Hurt, C., Jensen, T. K., Maitland, I., Richardson, S., Wakefield, J., \& Jarup, L. (2001). Risk of Adverse Birth Outcomes in Populations Living Near Landfill Sites. National Center for Biotechnological Information, 323, 363-368.

Elliott, P., et al. (2009). Geographic Density of Landfill Sites and Risk of Congenital Anomalies in England. Occupational \& Environmental Medicine, 66, 81-89. https://doi.org/10.1136/oem.2007.038497

EPA (2002). Ghana Landfill Guidelines. Environmental Protection Agency, Accra.

Fazzo, L. (2011). Ecological Studies of Cancer Incidence in an Area Interested by Dumping Waste Sites in Campania (Italy). Annali dell'Istituto Superiore di Sanita, 47, 181-191.

Foday, P., Y, X., \& Quangyen, T. (2013). Environmental and Health Impact of Solid Waste Disposal in Developing Cities: A Case Study of Granville Brook Dumpsite, Freetown, Sierra Leone. Journal of Environmental Protection, 4, 665.

https://doi.org/10.4236/jep.2013.47076

George, O., Nketiah-Amponsah, E., Samuel, N. A., Codjoe, G., \& Robert, F. (2014). How do Ghana's Landfills Affect Residential Property Values? A Case Study of Two Sites in Accra. Urban Geography, 35, 1140-1155. https://doi.org/10.1080/02723638.2014.945261

Hilburn, A. M. (2015). Participatory Risk Mapping of Garbage-Related Issues in a Rural Mexican Municipality. Geographical Review, 105, 41-60. https://doi.org/10.1111/j.1931-0846.2014.12044.x

Irma, D., Jelena, Đ., Nataša, E., Gordana, M., Vladan, Ć., \& Almin, D. (2016). The Impact of Leachate on the Quality of Surface and Groundwater and Proposal of Measures for Pollution Remediation. Journal of Environmental Protection, 7, 745-759. https://doi.org/10.4236/jep.2016.75067

Issahaku, F. (2014). Waste Management Strategies in an Urban Setting Examplefrom the Tamale Metropolis, Ghana. Journal of Waste Management, 2014, Article ID: 981054. https://doi.org/10.1155/2014/981054

ISWA (2015). Wasted Health: The Tragic Case of Dumpsites. ISWA.

Kasam, S. S., \& Agus, P. (2016). Pattern of Characteristics of Leachate Generation fromMunicipal Solid Waste Landfill by Lysimeter Experiment. International Journal of Environmental Science and Development, 7, 768-777. 
https://doi.org/10.18178/ijesd.2016.7.10.877

Liu, A., Ren, F., Lin, W., \& Wang, J. (2015). A Review of Municipal Solid Waste Environmental Standards. International Journal of Sustainable Built Environment with a Focus on Incinerator Residues, 4, 165-188. https://doi.org/10.1016/j.ijsbe.2015.11.002

Magda, M., Abu-Zuid, M., El-Salam, A., \& Gaber, I. (2015). Impact of Landfill Leachate on the Groundwater Quality: A Case Study in Egypt. Journal of Advanced Research, 6, 579-586. https://doi.org/10.1016/j.jare.2014.02.003

Malyuba, A., Hani, A., \& Hatem, A. (2013). Assessment of Heavy Metals and Organics in Municipal Solid Waste Leachates from Landfills with Different Ages in Jordan. Journal of Environmental Protection, 4, 344-352. https://doi.org/10.4236/jep.2013.44041

Manisalidis, I., Stavropoulou, E., \& Bezirtzoglou, E. (2020). Environmental and Health Impacts of Air Pollution: A Review. Frontiers Public Health, 8, Article No. 14. https://doi.org/10.3389/fpubh.2020.00014

McAllister, J. (2015). Factors Influencing Solid-Waste Management in the Developing World. Utah State University.

MDHSS (2018). Evaluation of Exposure to Landfill Gases in Ambient Air Bridgeton Sanitary Landfill Bridgeton. Missouri Department of Health and Senior Services.

Mudo, P., Monowar, H., Mido, N., \& Shivan, D. (2016). A Study on the Chemical Properties of Leachate and Its Effect on the Geotechnical Properties of Soil. International Journal of Engineering Technology Science and Research, 3.

Nang, B., Samuel, K., \& Steve, A. (2017). Solid Waste Management Challenges in Urban Areas of Ghana: A Case Study of Bawku Municipality. International Journal of Geosciences, 8, 494-513. https://doi.org/10.4236/ijg.2017.84026

Nathanson, J. (2015). Solid-Waste Management. Encyclopedia Britannica. http://www.britannica.com/EBchecked/topic/553362/solid-waste-management

Nyame, F. K., Tigme, J., Kutu, J., Kutu, J. M., \& Armah, T. K. (2012). Environmental Implications of the Discharge of Municipal Landfill Leachate into the Densu River and Surrounding Ramsar Wetland in the Accra Metropolis, Ghana. Journal of Water Resource and Protection, 4, 622-633.

Osahon, E. P. (2019). Health Effects of the Gbalahi Landfill Site on the Residents. Thesis, Department of Community Health and Family Medicine, School of Medicine and Health Sceince, University for Development Studies, in Partial Fulfillment for the Requirement for the Master of Public Health Degree (mph), Tamale.

Owusu, G., Oteng-Ababio, A., \& Afutu-Kotey, M., \& Robert, L. (2012). Conflicts and Governance of Landfills in a Developing Country City, Accra. Landscape and Urban Planning, 104, 105-113. https://doi.org/10.1016/j.landurbplan.2011.10.005

Owusu-Sekyere, E., Osumanu, I., \& Yaro, J. (2013). Dompoase Landfill in the Kumasi Metropolitan Area of Ghana: A 'Blessing' or a 'Curse'? International Journal of Current Research, 2, 87-96.

Périou, C. (2012). Waste: The Challenges Facing Developing Countries. Proparco's Magazine, 15, 1-27.

Puopiel, F., \& Owusu-Ansah, J. (2014). Solid Waste Management in Ghana: The Case of Tamale Metropolitan Area. Journal of Environment and Earth Science, 4. https://www.iiste.org/

Samuel, T. K. (2014). Solid Waste Management in Urban Areas of Ghana: Issues and Experiences from Wa. Journal of Environment Pollution and Human Health, 2, 110-117.

Schoeman, J., Steyn, A., Slabbed, J., \& Venter, E. (2003). Treatment of Landfill Leachate from Hazardous and Municipal Solid Waste. Report to the Water Resource Commission. 
Syeda, N. (2014). Open Dumping of Municipal Solid Waste and Its Hazardous Impacts on Soil and Vegetation Diversity at Waste Dumping Sites of Islamabad City. Journal of King Saud University-Science, 26, 59-65. https://doi.org/10.1016/j.jksus.2013.08.003

Thompson, I. A. (2012). Domestic Waste Management Strategies in Accra, Ghana and Other Urban Cities in Tropical Developing Nations. Accra.

Ugwoha, E., \& Emete, K. (2015). Effects of Open Dumpsite Leachate on Groundwater Quality: A Case Study of Alakahia Dumpsite in PortHarcourt, Nigeria. Journal of Environmental Studies, 1, 8. https://doi.org/10.13188/2471-4879.1000002

Valencia, R., Van der Zon, R., Woelders, H., Lubberding, H., \& Gijzen, H. J. (2009). Achieving "Final Storage Quality" of Municipal Solid Waste in Pilot Scale Bioreactor Landfills. Waste Management, 29, 78-85. https://doi.org/10.1016/j.wasman.2008.02.008

Yadav, Y., Ragini, G., \& Tenguriya, R. (2018). Management of Heavy Metal Pollution by using Bacterial Biomass. International Journal of Biotech Trends and Technology (IJBTT), 8. https://doi.org/10.14445/22490183/IJBTT-V8I1P603

Zhu, D., Asnani, P., Zurbrügg, C., Anapolsky, S., \& Mani, S. (2008). Improving Municipal Solid Waste Management in India: A Sourcebook for Policy Makers and Practitioners. World Bank. https://doi.org/10.1596/978-0-8213-7361-3 